\title{
Exploration and Practice of Talents' Training Model for the Application-oriented Universities
}

\author{
Wang Yunlong \\ Heilongjiang Institute of Technology \\ Automotive Engineering Department \\ Harbin, China \\ yunlong14666@163.com
}

\author{
Zhang Hongtian \\ Heilongjiang Institute of Technology \\ Automotive Engineering Department \\ Harbin, China \\ zhanghongtian808@126.com
}

\begin{abstract}
- when the higher education is popular education stage, the talent training mode will be faced with reform and transformation. The reform of education and teaching is important content that how to train the social development need, to shorten difference between talent training and corporation requirement, to innovate talent training mode. Heilongjiang Institute of Technology is the applicationoriented university, the aim is training applied, composite, innovation engineering technical talent, insist on training idea of the diversification aim, the open system, the elastic project, the dynamic process, the standardization quality, build talent training guideline of one thread, two system, three platform, four combination, five quality monitoring system, construct talent training system of the application-oriented universities. (Abstract)
\end{abstract}

Keywords-Application-oriented Universities; Training; Training Idea; Training Mode (key words)

Talents' $^{\prime}$

\section{INTRODUCTION}

Higher education had entered into popular education stage in China, had experienced for many years. Gradually talent training was classified as academic talent, applicationoriented talent, skill type talent. The academic talent was trained in the university of 985 and 211 type, the skill type talent was trained in the vocational colleges and skilled workers' school, the application-oriented talent was more trained in the local colleges. Shuttle type is the framework of talent training, although the colleges and undergraduate are more, the fashion and method of talent training still are not specific and ripe. Application-oriented universities are important part of local engineering colleges, has important task of training application-oriented undergraduate. The pressing matter of moment is How to change the foregone vocational training mode, as soon as possible come into education idea of application-oriented university, establish training mode of satisfying demand for region development and higher level, application-oriented talent with specialty attainment and innovation spirit for application-oriented universities, especially newly-built undergraduate universities $^{[1,2,3,4]}$.

Our college is application-oriented universities, talent training mode is exceptional. Shorter was time of into undergraduate, but we had obtained harvest for talent training facet of application-oriented university, formed talent training idea of multiple goal, open system, flexible project, dynamic process, quality standardization, built talent training guideline of one backbone, two systems, three platforms, four combinations, five quality monitoring systems. i.e. one backbone was training engineering capability and making, two systems were theory and practice teaching, three platforms were general basic education, gradual specialty education, open integration education, four combinations were combining basic platform with specialty module, combining classroom teaching with project teaching, combining teaching practice with scientific research and production practice, combining school education with corporation training, five quality monitoring systems were teaching supervision system, student appraising teacher system, teaching evaluation system, information feedback and disposal problem system, society demand and quality appraisement system.

\section{TALENT TRAINING IDEA}

We advocated that talent training goal was multiple, training project was flexible, teaching process was dynamic, teaching quality was standardization for talent training idea of our school.

\section{A. Multiple Goal}

The multiple goal is root of training application-oriented undergraduate, our school is application-oriented college, shoulders important task of region economy society development, trains application-oriented type, complex type, innovative type engineering technology talent for fitting region economy society development, fitting specialty knowledge integrated, engineering technology innovated.

\section{B. Open System}

Our college insists on training talents, running socialization and internationalization of school, builds open system of talent training, designs scientifically open project of talent training, realizes comprehensive, tridimensional, open system of talent training built by innovating and optimizing course system, teaching mode, resource utilized inside and outside the school, intercollegiate exchange, cooperation between school and enterprise.

\section{Flexible Project}

Training plan is the core for talent training in the universities, is directly related to a series of core problem whether the talent training target is realized, whether knowledge structure is reasonable, capability is formed, and so on. For the talent training scheme design our school used 
top layer design method to rearrange the general education, professional education, comprehensive education platform, built modular curriculum on the three educational platform, made the talent training scheme has the flexibility, openness, autonomy through flexible combination of curriculum module.

\section{Dynamic Process}

We hope to combine student trained with unity and diversity, harmonize student developed with individuality and generality by dynamic teaching process, so as to enable students to become the master of learning, life in the university, to create the condition of interest, potential and personality for the students, to give full play to students' own expertise, to pay attention to the cultivation of students' Humanities quality.

\section{E. Quality Standardization}

The quality of teaching is standardization through the standard teaching management, perfect system of quality monitoring and evaluation, system of the teaching management, system of teaching supervision, system of teaching evaluation, to ensure students involved in teaching work standardization, makes student taught in a standardization system.

\section{TALENT TRAINING GUIDELINE}

\section{A. One Backbone}

Since two colleges was combined, we always insist on orientation of talent training that trains the High level application-oriented special talent with comprehensive development of morality, intelligence, sport, solid foundation, broad knowledge, practical ability, comprehensive quality, Spirit of innovation etc. It was one backbone that train students' engineering ability and engineering quality, run through the whole process of application type, compound type, innovative engineering talents' cultivation.

\section{B. Two Systems}

As a new application-oriented undergraduate college, the whole teaching system included theory teaching and practical teaching, we had important task of training application type, composite type, innovative special technique talent to serve the regional economic and social development, to serve technology progress for the industry and enterprise, moreover realized construction with theory teaching system and practice teaching system, and realize both seamless jointing. It is necessary to train applicationoriented talent of meeting the regional economic and social development, technology progress of industry and corporation.

\section{1) System of Theory Teaching}

We made methods of theory teaching to proper innovation, for theory teaching, broke through the past oneway teaching way, reduced teaching content, increased practical and instructional teaching content, adopted teaching method of interactive, case-based, deliberation type. At the same time, invited engineering practice experts of enterprise to do theoretical teaching, vigorously implemented the project teaching, role played, problem decision-making of scene reappearance etc. We promoted comprehensively the networking, multimedia modern teaching means, improved continually multimedia courseware, found many kinds of service network accessorial teaching platform with making courseware, online $\mathrm{Q} \& \mathrm{~A}$, online exchanges, online selfstudy, network examination and so on, in order to expand teaching contents, improve the teaching effect.

\section{2) System of Practice Teaching}

We have done innovative design and setting to the practice teaching, changed main line of theory teaching to set experimental courses, experiment project and allocation of resources of experimental teaching in the past, brought use efficiency of the practice teaching resources low. The proportion reached more $80 \%$ through selecting and refining the experimental project, in order to improves project proportion of the comprehensive, design, innovative experiment ${ }^{[5]}$; At the same time, we increased period of the practical teaching, increased proportion of the practice teaching to reach the total credits $20 \%-25 \%$ of the practical teaching credits of engineering, total credits $20 \%$ of the practice teaching credits of arts and science; We advocated multiform open practice teaching, implemented time, content, equipment "three open", so that our students were not restricted by the experimental period, experimental items and equipment to complete independently experimental task. The students can choose online booking to complete self course experiment, enter into all-weather open laboratory to do graduating design, extracurricular science and technology innovation and teachers' research projects.

\section{Three Platforms}

We innovated on talent training system with modern educational concepts as the guide. Through three education platform of the general type of basic education, the Progressive type of speciality education and open type of integration education, emphasized "broad basic, high quality, strong ability, application", focused on training applicationoriented higher special talents of solid foundation, broad knowledge, practical ability, comprehensive quality, Spirit of innovation, comprehensive development of morality, intelligence, sport, need of sufficing production, construct, management, service.

\section{1) General Basic Education}

Talent training localization of our school is "broad basic, high quality, strong ability, application", strengthen training of students' humanities social science, natural science foundation and basic skills, setting speciality courses introduction, speciality basic courses to tamp basic education. We built general education platform of elective courses and required courses, required courses consisting of the ideological and political theory course, foreign language, sports, computer basis, higher mathematics etc; elective courses were chosen from series module of general education electives, each module content was combined with education development and needs of talent culture quality of the social to be timely supplement and update, was a 
dynamic, both Arts and science, interdisciplinary, continuous development general education elective course system.

\section{2) Gradual Specialty Education}

We referred comprehensively "CDIO" engineering education idea for speciality education, design courses system of speciality education, built speciality education platform of depending on practice education with the core of strengthening the ability of engineering practice, engineering design ability and engineering innovation ability, outstanding students' practice ability training. Speciality practice teaching was four years continuously, from the first grade to the fourth grade, we organized students to do speciality practice in each academic year, trained students' basic experiment skill, computer and information technology application ability, literature retrieval ability, operation ability, engineering design ability, practice ability, language expression ability by arranging reasonably curriculum experiment and centralized practical teaching.

\section{3) Open Integrated Education}

The integrated education was constituted by quality development and innovation education, was open platform. We integrated effectively to improve the students' comprehensive quality with the objective of increasing students' comprehensive quality in the education of diathesis expanding. The required course part of the ideological and moral culture and practice included each thought education seminars and ideological and political theory course practice of military theory and policy situation seminars; The elective part included the qualification authentication, campus cultural activities, sports and so on. The students participated subject competitions, activities of science and technology, entrepreneurship education in the innovation and entrepreneurship education.

\section{Four Combinations}

We have implemented training of application-oriented talent for comprehensive speciality quality in the university, provided guarantee for engineering technology talent with application type, composite type, innovative type for "broad basic, high quality, strong ability, application", by combining basic platform with specialty module, combining classroom teaching with project teaching, combining teaching practice with scientific research and production practice, combining school education with corporation training.

1) Combining Basic Platform with Specialty Module

We trained application-oriented higher speciality talent by combining general basic education platform with gradual speciality education. We designed aboratively basic course system and speciality course module, integrated necessary knowledge structure and edified spirit quality, impenetrated in course teaching, was propitious to train higher integrative quality, stronger practice capability, better innovation spirit speciality talent. We engaged wide calibre speciality education on the basic of general education, from regarding barely knowledge imparted to strengthening speciality ability, increasing speciality quality. "knowledge, ability, quality" is dialectic unification, knowledge is imparted with training ability and increasing quality, at the same time pay attention to train student' innovation ability and increase ideology morality quality.

2) Combining Classroom Teaching with Project Teaching

Project teaching was carrier with project, the teacher and the student implemented together one integrated project, we taught knowledge, skill and correlation matters of project need by classroom teaching, it was active action that trained student' profession ability, speciality skill, project management and integration quality.

We introduced project teaching into classroom teaching in the speciality education, provided bigger space of innovation thinking and space of freedom creating, train student' practice ability and plan ability, expanded harvest of classroom teaching, exerted maximumly student' interest, personality and character, boosted student' self-confidence, realized self-worth, enhanced student' team idea, organizing ability, harmony ability, sociality ability, increased student' viability, meeting emergency ability, innovation ability, psychology enduring and society competition.

3) Combining Teaching Practice with Scientific Research and Production Practice

The aim of teaching practice was training practice level and ability, setting the concentrative practice segment with speciality integration experiments, society inquisitions, various exercitations, course designs, graduation papers. We innovated on exercitation mode by the industry and corporation, combined teaching practice with scientific research and production practice, established cooperating relation of scientific research, production practice with 150 more institutes and corporations in the home and abroad. For example the Civil and Architectural Engineering College, exercitation mode was innovated on that from the teachers lead students to visit building sites to 1-2 students was arranged to actual post of corporation to work in the road built sites of inside and outside the province. The students participated in engineering building as a technology person and charged producing duty in the whole exercitation course. The students did graduation papers with actual engineering practice, the practice ability and engineering quality exercised adequately in the actual, intricate engineering practice, at the same time many students had obtained employment, realized nicer effect of graduating to employment immediately.

4) Combining School Education with Corporation Training

It was absolutely necessary means that we trained application-oriented talent with contenting demand of region economy, better basic, profound knowledge, practice ability etc. For shortening interval of between talent training of school and demand of corporation, we run school actively with the corporations, implemented talent training of 'order type'. In 2004, we cooperated with the United States Caterpillar Inc and Australia Wister (China) Company in actualizing talent training of 'Hongtu project', the project was only one cooperation project of training engineer of Caterpillar for product service in the Asia Pacific Region for 16 schools of the global 'Hongtu project'. In the cooperation 
project, recruited two grade students into 'Hongtu project classes' by examination each year, the training plan was established by the school and the corporation according to demand of corporation in the follow two years study, for the follow two years of the school, the students studied in the center of engineering training and CAT lab of Wister (China) Company, 2/3 was the period of practice teaching, the students were trained by engineer of Wister Company; for exercitation of outside school, the students were sent into maintain basis of Wister Company, one technology engineer coached 2-3 students to exercitation, participated in maintain service of machine products as maintain engineer. by training mode of 'order type' with the corporation, the students entered earlier engineering environment, tasted excellent culture of corporation and advanced manage mode, realized 'zero distance' contact of between talent training of school and demand of corporation.

\section{E. Five Quality Monitoring Systems}

The important guarantee was monitoring systems of teaching quality for realizing successfully the plan of talent training in the college. We established a suit of more integrated teaching evaluation systems and quality monitoring systems, it was participated in that teaching evaluation and quality monitored by the correlative person of school, corporation, industry etc, built the all-around monitoring systems of talent training quality not only to assure teaching successfully, teaching quality, teaching feedback but also to introduce talent demand and quality request of society.

\section{1) Teaching Supervision System}

We established teaching quality monitoring segment such as listening prelection of two levels supervision, listening prelection of teaching manager, listening prelection of leader, listening prelection of teacher, assisted teachers with innovating on teaching means, resolved existent problems of teaching process, enhanced continuously teaching quality. Two levels supervisor did teaching supervision works according to plan each semester, summarized works, exerted on important action in teaching quality supervision.

2) Student Appraising Teacher System

We established <the management rule of students appraising teacher in Heilongjiang institute of technology>, designed tables and database of students appraising teacher according to 'teaching attitude', 'teaching content', 'teaching means', 'teaching effect' four aspects, ten indexes. In three years the students participated in teaching quality appraisement about fifty thousand person-time, the teachers were appraised about three thousand person-time, including the whole teachers. By several years practice the students appraising teacher gained amelioration, approving of spacious teachers and students, exerted on active action of improving teaching works for the teachers.

\section{3) Teaching Evaluation System}

We organized regularly expert to evaluate teaching state and level(including idea of running school, teacher procession, teaching innovation, teaching management, teaching quality), courses and specialty, graduate paper and examination paper(including graduate paper selecting subject, ability level, production quality, examination paper evaluation and management etc), made continuously teaching management and teaching document to criterion.

4) Information Feedback and Disposal Problem System

We established one teaching messenger procession with two hundred more different grade, different speciality students, cycled students each year, moreover new messengers can join teaching messenger procession by special training. Office of educational administration should do timely feedback, disposal for feedback problem of the messengers. We collected all teaching information and disposal information to the messengers, got good appraisement of the students. We constituted system of the information feedback and disposal problem with the teachers visiting employment market, demand of speciality setup, talent training mode and graduate work for the corporations, so that provided reference for teaching department, adjusted duly speciality configuration and talent training mode.

5) Society Demand and Quality Appraisement System

We had received duly appraisement and intendance of the society in the whole talent training process, emended continuously the plan of talent training according to talent demand change of the society, established quality appraisement system of speciality setup, teaching quality, talent training from the corporations and the industries, made the graduates demand exceeds supply in the aboil employment market.

\section{CONCLUSIONS}

By investigating for the corporations recruiting our graduates, think widely more excellent talent with work ability, ideology character, duty consciousness, dedicated spirit, well-knit speciality theory, can adapt rapidly role, handle effectively speciality knowledge, become technology elite and business expert of the corporations. Our application-oriented talent received universal authorization of the society basing on talent training idea of 'one thread, two system, three platform, four combination, five quality monitoring system'.

\section{ACKNOWLEDGEMENT}

This work was supported by ordinary institutions of higher learning young academic backbone of Heilongjiang Province support program (1252G051).

[1] Wang Xiaohu, Wang Lele, Li Xiaohui. Cooperative education of corporation, school and institute: the important approach of application-oriented talent training. Modern Education Science, vol. 5, pp. 173-175, 2010

[2] Li Jihuai, Wang Lijun. Rational regression of engineering education and distinguished engineer training. Heilongjiang Researches on Higher Education, vol. 3, pp. 140-142, 2011.

[3] Zhang Laibin. Exploring and thinking of higher engineering education innovation in the big engineering view. China Higher Education Research, vol. 8, pp. 8-10, 2009.

[4] Li Peigen. How to be excellent for engineer educating and training. China Higher Education Research, vol. 6, pp. 13-14, 2011.

[5] Zhang Hongtian. Exploring and practicing for establishing open system of practice teaching, training application-oriented engineering talent. China University Teaching, vol. 8, pp. 73-76, 2011. 